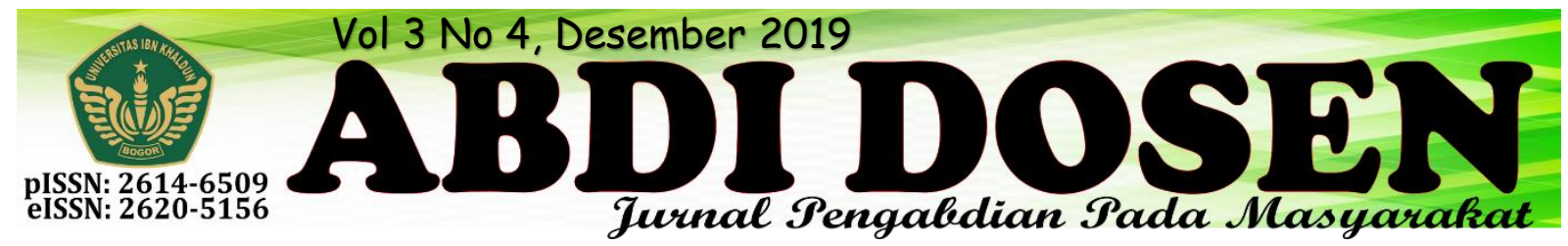

\title{
PENINGKATAN PEMBERDAYAAN MASYARAKAT MELALUI PENGEMBANGAN PRODUK LOKAL (KERIPIK DAUN JAMBU BIJI) DESA GUNUNG MULYA
}

\author{
Diah Yudhawati ${ }^{1}$, Alni Novianti Wijaya, Delfa Kapriadi ${ }^{2}$ \\ diah@uika-bogor.ac.id \\ Fakultas Ekonomi dan Bisnis Universitas Ibn Khaldun ${ }^{1}$, Mahasiswa KKN Kelompok 04 Tahun $2018^{2}$
}

\begin{abstract}
ABSTRAK
KKN merupakan kegiatan pengabdian kepada masyarakat di daerah tertentu atau lembaga pendidikan, dilaksanakan secara kelompok, terintegrasi antar jurusan, terkoordinasi di tingkat fakultas. Kegiatan KKN (Kuliah Kerja Nyata) bertujuan untuk memberikan pengalaman kerja nyata di lapangan dalam bidang membentuk sikap mandiri dan tanggung jawab dalam pelaksanaan pekerjaan di lapangan. Selain itu, KKN juga bertujuan untuk membantu masyarakat dalam meningkatkan taraf pengetahuan dan keterampilan sehingga diharapkan dapat meningkatkan kesejahteraannya. Program kelompok di kampung Puswa Desa Gunung Mulya merupakan program yang lebih menekankan kepada tema Pemberdayaan Masyarakat melalui Pengembangan Produk Lokal dengan membuat produk baru yaitu "Keripik Daun Jambu Biji” yang dikelola oleh kelompok usaha mandiri dan diharapkan mampu menjadi usaha masyarakat yang dapat berkembang dengan baik sehingga menjadi tambahan pendapatan keluarga. Adapun program lain yang telah dilaksanakan antara lain program yang berkaitan dengan bidang pendidikan, agama, kesehatan, teknologi dan informasi, kesehatan dan hukum yang menjadi program kerja kelompok KKN. Secara umum, kegiatan KKN di kampung Puswa Desa Gunung Mulya, Kecamanatan Tenjolaya Bogor berjalan dengan baik dan lancar. Hal itu dikarenakan antusiasme warga kampung Puswa yang sangat baik. Pelaksanaan programprogram KKN tersebut diharapkan dapat bermanfaat bagi seluruh pihak yang terkait sebagai pengaplikasian dan kompetensi pemiliknya.
\end{abstract}

Keyword : pemberdayaan, pengembangan, produk lokal, keripik daun jambu

\section{PENDAHULUAN}

\section{Latar Belakang}

Masyarakat secara sosiologis merupakan tujuan terakhir dari program akademik apapun yang ada dalam sebuah lembaga pendidikan. Jurusan atau program studi apapun yang diambil dalam proses akademik seorang mahasiswa setiap ilmu yang didapat dalam aktivitas akademik berupa perkuliahan, praktikum dan sebagainya pada dasarnya memiliki tujuan akhir supaya bisa diaplikasikan di masyarakat dan bermanfaat bagi masyarakat.

$$
\text { Kuliah Kerja Nyata (KKN) }
$$
merupakan salah satu dari sekian program akademik terpadu yang ada pada sebuah perguruan tinggi yang berisi akumulasi kegiatan berupa pendidikan, penelitian dan pengabdian masyarakat secara nyata. Program KKN bersifat intrakurikuler dan 
merupakan tuntutan akademik yang wajib dipenuhi oleh mahasiswa, baik secara individual ataupun kelompok, yang dimaksudkan sebagai wadah pembelajaran yang cukup strategis dalam mengembangkan potensi, wawasan dan kemampuan dimiliki serta untuk membuka akses komunikasi dan mengintegrasikan dirinya dalam kehidupan sosial yang bertumpu pada bidang pendidikan, ekonomi, sosial hukum, agama, kesehatan dan teknologi tepat guna.

Ini menunjukkan bahwa KKN berada pada posisi yang cukup penting dalam menempuh pendidikan di perguruan tinggi. Begitu pula dalam program KKN yang dilaksanakan oleh Universitas Ibn Khaldun Bogor, selain berfungsi sebagai sarana aplikasi dari tri dharma perguruan tinggi mahasiswa dalam proses pendidikannya, KKN juga merupakan wujud komitmen UIKA Bogor sebagai perguruan tinggi untuk memenuhi tuntutan dan dinamika kebutuhan masyarakat; yakni bahwa ilmu, sikap dan keterampilan civitas akademikanya harus diamalkan secara nyata di masyarakat.

Kegiatan KKN yang dilaksanakan di LPPM Universitas Ibn Khaldun Bogor di tahun 2018 ini akan dilakukan dilokasi terfokus dengan batasan wilayah Kecamatan Ciampea, Kecamatan Tenjolaya, Kecamatan Pamijahan, Kecamatan Cibungbulang, Kecamatan Leuwiliang dan Kecamatan Leuwisadeng.

Desa Gunung Mulya merupakan salah satu dari beberapa desa yang ada di Kecamatan Tenjolaya Kabupaten Bogor. Dari segi potensi, Desa Gunung Mulya merupakan tipikal desa yang memiliki sumber daya alam yang sangat mendukung untuk aktivitas pertanian, maupun aktivitas lainnya seperti pembuatan kerajinan tangan dan olahan makanan dengan bahan baku yang bersumber dari alam. Warga Desa Gunung Mulya memiliki keterampilan dalam pembuatan kerajinan tangan seperti pembuatan sepatu, anyaman bambu, tusuk sate, dan lain-lain.

Namun selama ini keterampilan tersebut belum di maksimalkan menjadi usaha potensial yang bisa menjadi pendapatan tambahan bagi keluarga. Pengrajin Desa Gunung Mulya hanya mampu menjual hasil pertanian dan kerajinan tangan nya ke pengepul, belum mampu menjual secara langsung kepada konsumen yang berdampak pada rendahnya harga jual. Komoditas yang paling banyak dihasilkan oleh warga yaitu buah jambu biji merah. Hampir setiap warga disana mempunyai kebun jambu yang panen nya 3 atau 4 hari sekali dengan jumlah hasil panen mencapai $100 \mathrm{~kg}$. Namun sangat disayangkan, nilai jual hasil panen tersebut sangat murah, hanya kisaran harga Rp 1.500 sampai dengan Rp 3.000 per kilogramnya.

Berdasarkan gambaran situasi tersebut, maka kami Mahasiswa KKN Kelompok 04 Universitas Ibn Khaldun Bogor melakukan kegiatan pengembangan produk lokal dengan membuat "Keripik Daun Jambu" sebagai cemilan khas kampung Puswa yang diawali dengan pembentukan Kelompok Usaha Mandiri. Dengan memanfaatkan komoditas lokal, diharapkan kelompok usaha ini dapat membantu meningkatkan perekonomian masyarakat Kampung Puswa Desa Gunung Mulya, Kecamatan Tenjolaya.

Kondisi Wilayah

\begin{tabular}{|c|l|c|}
\hline No & Keterangan & Berbatasan \\
\hline 1 & Utara & Desa Situ Daun \\
\hline 2 & Selatan & Desa Gunung Malang \\
\hline 3 & Barat & Desa Tapos Dua \\
\hline 4 & Timur & $\begin{array}{c}\text { Desa Dramaga } \\
\text { Tamansari }\end{array}$ \\
& & \multicolumn{2}{c}{} \\
\hline
\end{tabular}




\begin{tabular}{|c|l|c|}
\hline 5 & Luas Daerah & $385 \mathrm{Ha}$ \\
\hline 6 & Jumlah & 6.833 Jiwa \\
& Penduduk & \\
\hline
\end{tabular}

\section{Potensi Kampung Puswa Desa Gunung Mulya}

Kampung Puswa memiliki kurang lebih 300 kepala keluarga dengan golongan ekonomi menengah ke bawah, dengan mata pencaharian sebagai petani, buruh tani, wiraswasta, pengrajin, dan pedagang. Masyarakat kampung Puswa mayoritas beragama Islam yang masih sangat kuat dengan semangat gotong royong dan persaudaraannya. Terbukti dengan partisipasi dan sambutan hangat warga kepada mahasiswa KKN yang senantiasa membuka tangan untuk saling membantu.

Kampung Puswa memiliki 4 sekolah yakni TK An-Nizhom, SDN Gunung

\section{METODE PENGABDIAN}

Kegiatan Kuliah Kerja Nyata (KKN) yang dilaksanakan pada tanggal 07 Agustus 2018 sampai dengan 07 September 2018 sebelumnya telah melalui serangkaian persiapan untuk mendukung terlaksananya program kerja KKN. Persiapan telah dilakukan baik oleh pihak LPPM selaku koordinator dan mahasiswa sebagai peserta KKN. Serangkaian persiapan yang tersebut antara lain: melakukan observasi ke desa tempat praktik lapangan yang dilakukan sebanyak dua kali, yaitu pada tanggal 31 Juli 2018 dan 2 Agustus 2018 yang meliputi observasi fisik dan nonfisik desa.

Pembekalan KKN yang dilakukan oleh pihak LPPM dengan materi pemberdayaan masyarakat melalui $\mathrm{KKN}$, serta materi yang terkait dengan teknis kegiatan KKN pada tanggal 30 Juli 2018. Kemudian melakukan koordinasi dengan Dosen Pembimbing Lapangan (DPL) KKN
Malang 01, SMP Al-Jihad dan SMA Al Jihad. Namun dengan tersedianya sarana pendidikan yang cukup, tidak diiringi dengan semangat pendidikan yang tinggi dari beberapa pihak baik dari tenaga pendidik maupun anak-anaknya.

Pelayanan bidang kesehatan yang ada di Kampung Puswa Desa Gunung Mulya yakni posyandu dan puskesmas. Posyandu ini diselenggarakan setiap tanggal 5 . Posyandu dikelola oleh kader-kader yang telah terpilih. Posyandu ini diperuntukkan untuk balita dan lansia. Sedangkan puskesmas beroperasai setiap hari seninsabtu. Namun kesadaran masyarakat terhadap kesehatan dan kebersihan lingkungan masih mini. Hal ini terlihat dari masih banyaknya tumpukan sampah yang tidak di kelola dengan baik serta kondisi lingkungan yang belum rapi.

kelompok secara efektif dan pembekalan dari fakultas. Mahasiswa KKN juga melakukan koordinasi, rapat, dan pertemuan dengan kelompok untuk membahas program kerja. Melakukan koordinasi dengan pihak masyarakat yang berkaitan dengan pelaksanaan kegiatan KKN.

Setelah melaksanakan pendataan dan observasi desa, baik dari segi fisik maupun nonfisik, selanjutnya merumuskan program-program kerja yang sesuai, melakukan koordinasi dan tindak lanjut pada DPL KKN atau Kepala Desa dan Ketua RW 03. Program-program yang ada meliputi program fisik dan non fisik.

Program fisik yang dilaksanakan yaitu pembuatan alat permainan edukasi anak, perawatan masjid, cek kesehatan gratis, pelatihan microsoft office dan power point, pembuatan kerajinan tangan dari 
sampah non organik dan kegiatan perilaku hidup bersih dan sehat (cuci tangan dan gosok gigi). Sedangkan program non fisik yang telah dilaksanakan antara lain: bimbel bahasa inggris dan arab, edukasi UU Lalu Lintas, pengenalan dasar-dasar informatika, edukasi kesehatan, pendampingan

\section{REALISASI PROGRAM}

Setelah melakukan persiapan dan pembekalan, serta pendataan dan observasi desa, selanjutnya merencanakan programprogram kerja yang akan dilakukan. Program-program kerja tersebut yaitu:

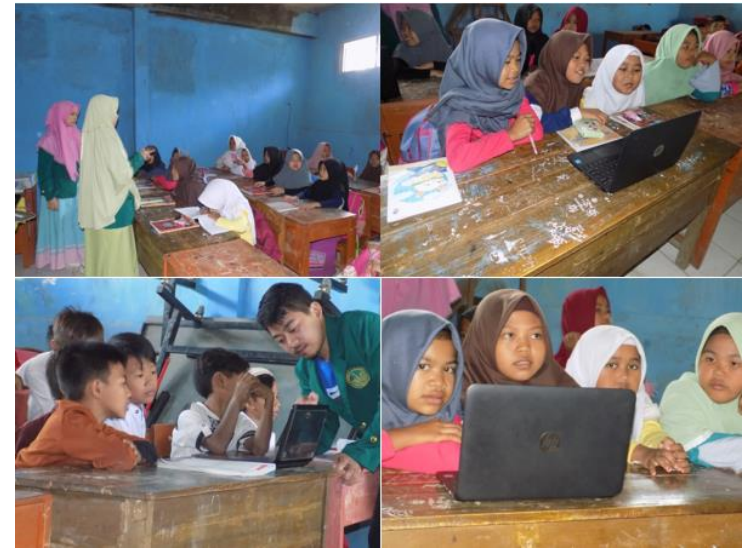

Pelatihan Microsoft Office (Word, Excell dan Power Point)

Saat ini perkembangan teknologi sudah semakin maju. Penguasaan terhadap komputer, software maupun hardware merupakan suatu keharusan yang harus dimiliki oleh setiap orang karena komputer merupakan salah satu produk perkembangan teknologi yang dapat dijadikan sebagai pintu masuk untuk mengenal teknologi yang lebih tinggi.

Komputer tidak akan berfungsi optimal apabila tidak ada upaya peningkatan kualitas Sumber Daya Manusia yang mampu menggunakan dan memanfaatkan aplikasi komputer untuk memecahkan masalah yang dihadapi. Pembelajaran dan pengenalan komputer lebih baik diajarkan di usia dini contohnya anak - anak SD, SMP dan SMA. Saat ini pengajian anak-anak dan ibu-ibu. Disamping program utama, kami juga membuat program tambahan sebagai penunjang kegiatan yang bersifat insidental yang dapat memberikan pengaruh positif terhadap masyarakat.

banyak anak - anak yang sudah dapat menggunakan teknologi untuk memenuhi kebutuhan seperti menggunakan Microsoft Word untuk membuat surat.

Microsoft Word merupakan suatu perangkat lunak pengolah kata. Aplikasi ini sangat berguna dalam pembuatan naskah, undangan atau surat sehingga aplikasi ini sangat penting untuk dipelajari. Oleh karena itu diadakan pelatihan Microsoft Word untuk anak- anak diharapkan anak - anak dapat mengerti penggunaan Microsoft Word dan dapat memanfaatkan Microsoft Word untuk keperluannya.

Tujuan : Mengenalkan dan meningkatkan kualitas SDM di lingkungan desa Gunung Mulya khususnya anak - anak SD, SMP dan SMA pada bidang komputerisasi khususnya dalam penggunaan Microsoft Word.

\section{Bimbel Bahasa Inggris serta} memberikan motivasi (Student's Collaborative using digital Technology (SCDT)).

Bahasa adalah alat yang sangat penting untuk Manusia berkomunikasi dengan yang lain untuk kemampuan bahasa yang diproduksi. Menurut Harun Rasyid, Mansyur dan suratno (2009, p126), Bahasa ialah struktur serta makna yang terbebas dari penggunanya sebagai sebuah tanda guna menyimpulkan maksud dan tujuan. Bahasa sangatlah penting dan dibutuhkan dalam kehidupan umat manusia. Apabila bahasa itu tidak ada maka sseorang tidak dapat untuk menyampaikan maksud dan 
tujuannya, yang hingga akhirnya akan muncul kebisuan yang tidak menghasilkan apa-apa.

Dalam belajar bahasa, khususnya bahasa inggris, Menempatkan siswa untuk berkolaboratif merupakan teknik yang sangat produktif ketika mengajar bahasa asing yaitu Bahasa Inggris. Menurut efendi "placing students in Group was the first step in implementing Collaborative technique" (Efendi, 2009, p1).

Teknologi adalah pengembangan dan penerapan berbagai peralatan atau sistem untuk menyelesaikan persoalan-persoalan yang dihadapi manusia dalam kehidupan sehari-hari (M. Maryono). Seperti yang kita tahu bahwa pendidikan di indonesia sangat lemah, hal itu disebabkan karena kebanyakan guru menyampaikan materi hanya sekedar menyampaikan saja tanpa membuat metode yang membuat siswa tertarik, khususnya dalam belajar bahasa inggris, di kurikulum k-13 ini semua fasilitas sekolah seudah menggunakan (new technology), karena keterbatasan fasilitas di sekolah kp.puswa, maka dari itu kita membuat metode menggunakan digital teknologi agar memberikan anak-anak kampung puswa antusias dalam belajar bahasa inggris.

Guru mengajar dengan mengunakan spidol dan kapur memang masih bisa memberikan pemahaman kepada murid, tapi dengan kami menggunakan teknologi Lcd Proyektor, Laptop guna untuk memfasilitasi pelaksanaan pembelajaran bahasa inggris menggunakan Lagu, menonton video motivasi,akan memberikan banyak pesan multimedia dan visual yang memberikan ilmu pengetahuan dan mudah dicerna. ini merupakan usaha khusus dalam bentuk teknologi adalah sistem yang diciptakan manusia untuk sesuatu tujuan tertentu. Intinya adalah untuk mempermudah manusia dalam memperingan usahanya, meningkatkan hasilnya, dan menghemat tenaga serta sumberdaya yang ada.

Tujuan : untuk anak-anak kampung puswa,Untuk memecahkan masalah belajar bahasa inggris, untuk meningkatkan kinerja pembelajaran, memberikan motivasi, berfikir kritis, kreatif, terampil dan aktif , Membentuk sikap dan karakter.

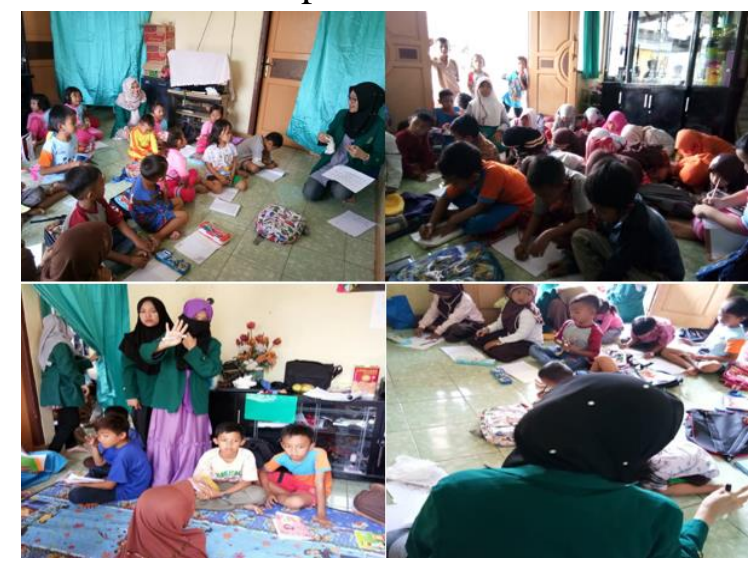

\section{Program Bimbel Bahasa Arab}

Tujuan : pembelajaran bahasa Arab adalah: untuk dapat memahami al-Quran dan hadist sebagai sumber hokum ajaran islam; untuk dapat memahami buku-buku agama dan kebudayaan islam yang ditulis dalam bahasa Arab, untuk dapat digunakan sebagai alat pembantu keahlian lain (supplementary) untuk membina ahli bahasa arab, yakni benar-benar profesional. Di samping itu tujuan pengajaran bahasa Arab adalah untuk memperkenalkan berbagai bentuk ilmu bahasa kepada peserta didik yang dapat membantu memperoleh kemahiran berbahasa, dengan menggunakan berbagai bentuk dan ragam bahasa untuk berkomunikasi, baik dalam bentuk lisan maupun tulisan 


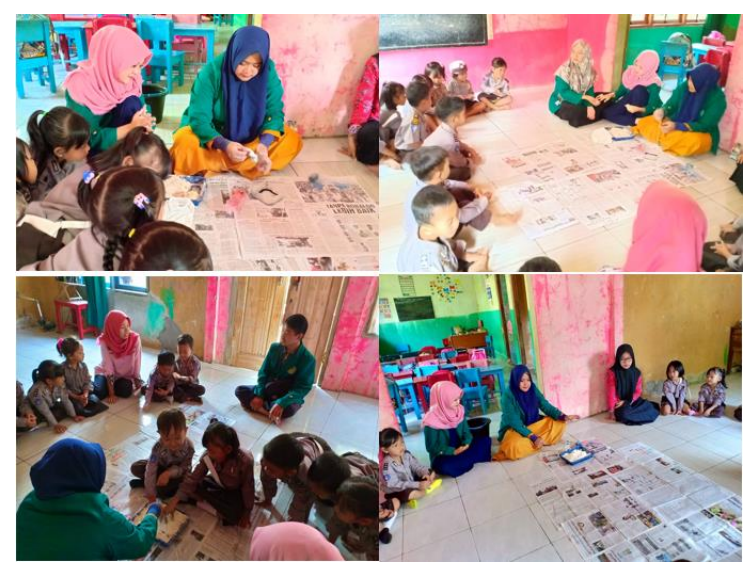

Pembuatan Permainan Alat Edukatif (APE)

Alat permainan adalah semua alat yang digunakan anak untuk memenuhi naluri bermainnya, sedangkan alat permainan edukatif adalah alat permainan yang sengaja dirancang secara khusus untuk kepentingan pendidikan (Tedjasaputra, 2001). Alat permainan edukatif untuk anak TK adalah alat yang sengaja dirancang secara khusus untuk meningkatkan aspekaspek perkembangan anak. Menurut Suryadi (2007), bahwa alat permainan edukatif adalah alat yang dirancang khusus sebagai alat untuk bantu belajar dan dapat mengoptimalkan perkembangan anak, disesuaikan dengan usia dan tingkat perkembangannya.

Tujuan :

- Memperoleh potensi yang ada pada anak

- Anak akan menemukan kelemahan dan kekuatan dari dirinyaa dan kemampuan serta minat kebutuhannya

- Memberi peluang bagi anak untuk berkembang seutuhnya baik fisik, intelektual bahasa dan prilaku (psikososial atau emosional)

- Memotivasi anak agar memiliki rasa ingin tahu yang tinggi.

Pengelolaan penggunaan APE senantiasa disesuaikan dengan tema yang berjalan dan dalam penggunaanya senantiasa diseduaikan dengan ketersediaan alat permainan dengan jumlah anak didik. Begitu juga, guru ditekankan untuk terampil dalam menggunakan alat permainan yang sifatnya masih baru dan juga alat permainan yang terbatas.

Ketepatan penggunaan APE dapat diperoleh ketika alat permainan yang digunakan mampu memberikan dampak terhadap aspek pengembangan anak yang terdiri dari kemampuan kognitif, seni, bahasa, fisikmotorik, pengembangan berhitung permulaan dan pengembangan baca tulis serta dapat mengembangkan pembiasaan untuk melatih kemandirian anak, emosional anak dan memupuk kebersamaan.

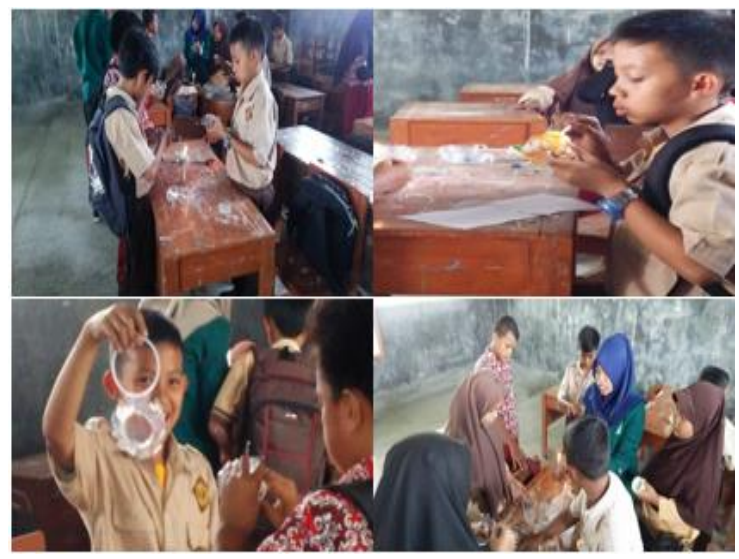

Penyuluhan pemilahan sampah organik dan anorganik

Kegiatan ini dilaksanakan sebagai upaya untuk memberikan pemahaman, pengetahuan dan meningkatkan kesadaran akan pentingnya kebersihan lingkungan.

Tujuan: Memberikan pemahaman, pengetahuan dan meningkatkan kesadaran akan pentingnya kebersihan lingkungan. 


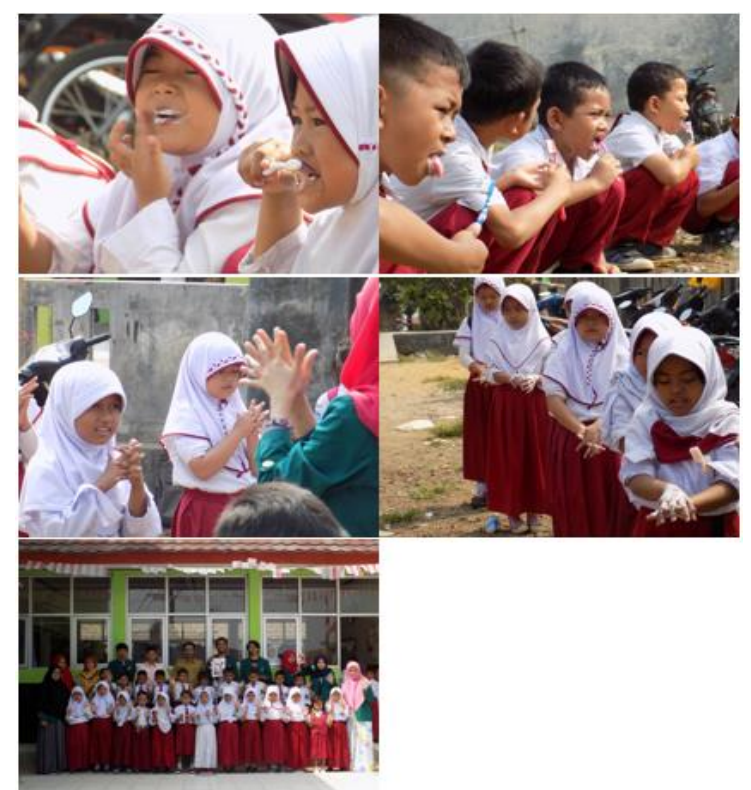

Praktek mencuci tangan dan menggosok gigi yang baik dan benar

PHBS di sekolah merupakan sekumpulan perilaku yang dipraktikkan oleh peserta didik, guru dan masyarakat lingkungan sekolah atas dasar kesadaran sebagai hasil pembelajaran, sehingga secara mandiri mampu mencegah penyakit, meningkatkan kesehatannya, serta berperan aktif dalam mewujudkan lingkungan sehat. Tujuan: Memberikan pemahaman, pengetahuan dan meningkatkan kesadaran akan pentingnya perilaku hidup bersih dan sehat.

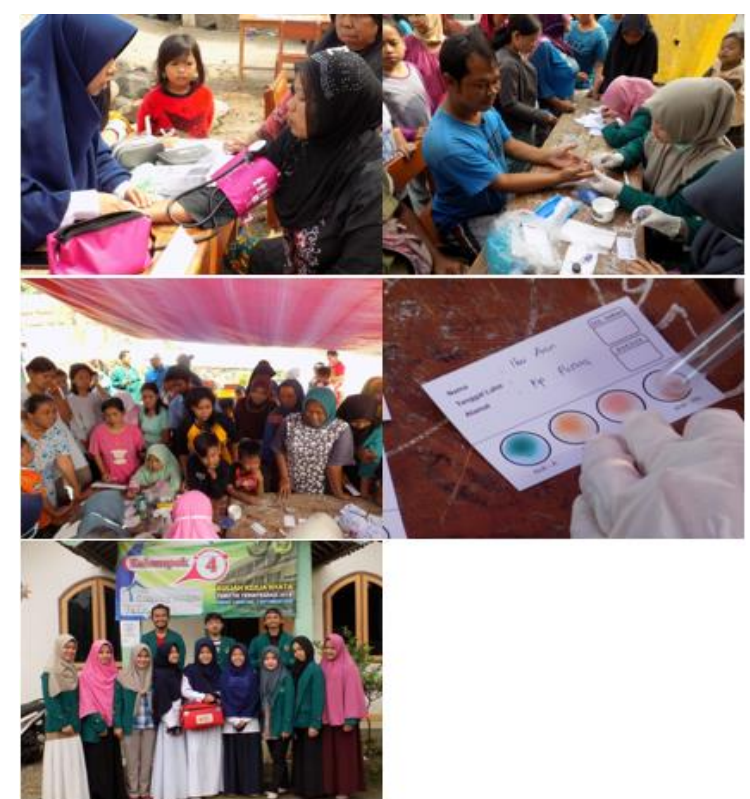

Edukasi kesehatan dan cek kesehatan gratis

Kegiatan ini dilaksanakan sebagai upaya untuk memberikan pemahaman, pengetahuan dan meningkatkan kesadaran akan pentingnya kesehatan diri sendiri supaya mengetahui penyakit yang di deritanya lebih awal.

Tujuan :

- Mengetahui penyakit yang diderita sejak awal.

- Mengetahui jenis-jenis penyakit, penyebab, dan solusi apa yang harus di lakukan.

- Mengetahui jenis-jenis golongan darah yang dimiliki.

- Mengetahui berat badan yang ideal.

- Mengetahui tekanan darah yang normal. 


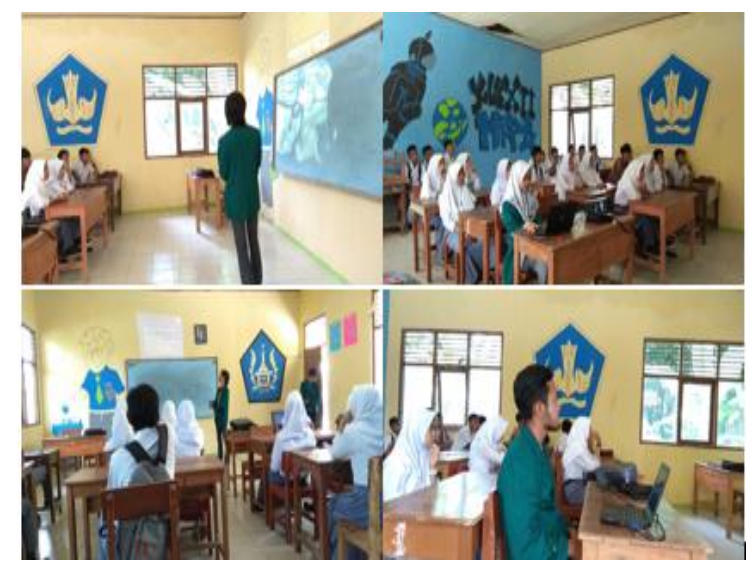

Penyuluhan Sosialisasi dan Edukasi Undang-Undang Lalu Lintas

Kegiatan ini dilaksanakan sebagai upaya untuk memberikan pemahaman, pengetahuan dan meningkatkan kesadaran akan pentingnya Tertib Lalu Lintas

Tujuan: Memberikan pemahaman, pengetahuan dan meningkatkan kesadaran akan pentingnya tertib lalu lintas.

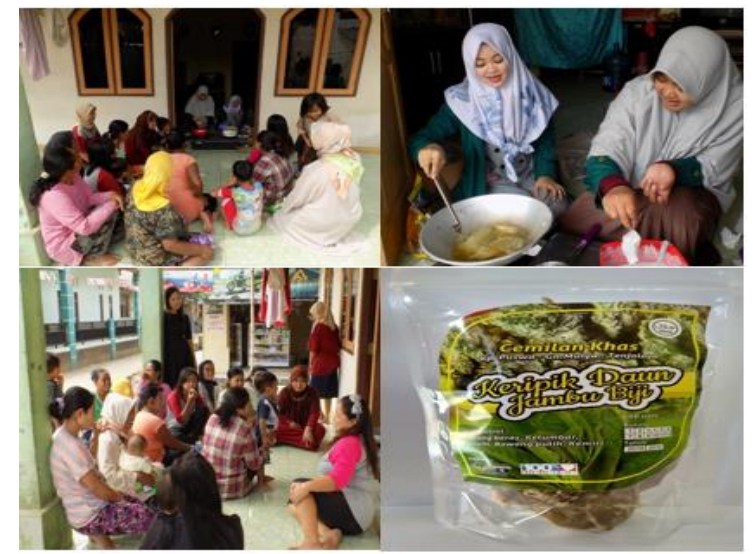

Sosialisasi Kewirausahaan Islami \& Pengembangan Produk Lokal (keripik daun jambu)

Tujuan :

- Memberikan edukasi kepada siswa mengenai wirausaha islami.

- Membuat kelompok usaha mandiri bagi ibu-ibu warga kampung puswa dalam rangka meningkatkan pendapatan penghasilan bagi keluarga dan peningkatan skill dan keterampilan.

- Remaja dapat berperan aktif membantu kelompok usaha mandiri sebagai sales marketing untuk memasarkan produk yang sudah di produksi melalui situs online.

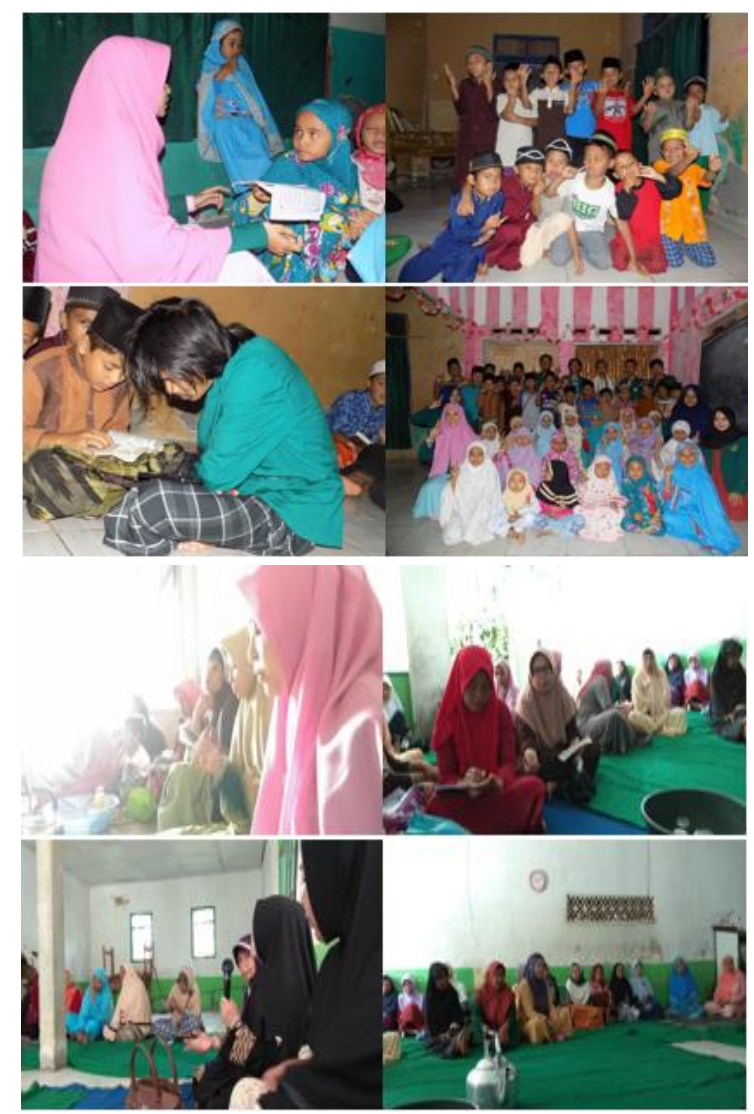

Pendampingan pengajian anak-anak dan ibu-ibu

Tujuan :

- Membimbing dalam membaca iqra dan Al Quran.

- Membimbing anak-anak dalam menghafal surat-surat pendek Al Quran.

- Mengakrabkan mahasiswa KKN UIKA kelompok 04 dengan anak-anak dan ibuibu kampung Puswa. 


\section{B. Program Tambahan}

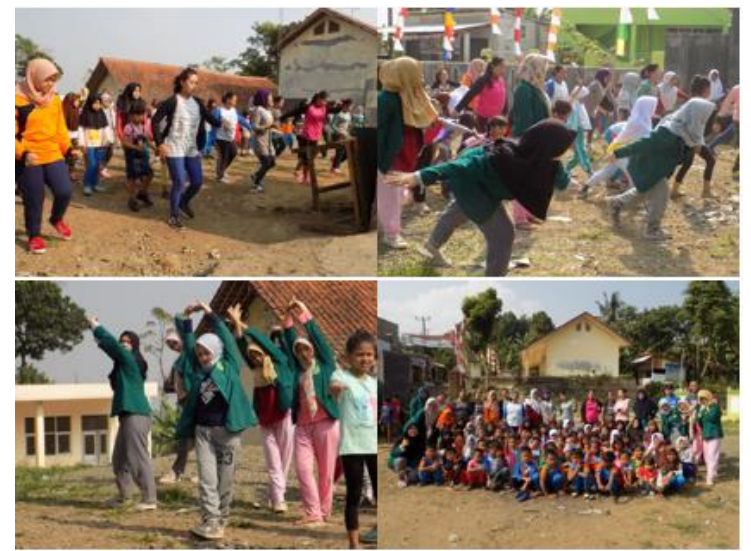

\section{Senam Sehat Ceria}

Senam adalah suatu kegiatan olah raga jasmani yang dilakukan dalam durasi waktu 30 menit dengan cara menggerakkan seluruh anggota tubuh secara teratur yang dilakukan sebanyak 10 macam gerakan/lebih.

Tujuan: Meningkatkan aktivitas olahraga dan mengajarkan cara agar selalu sehat.

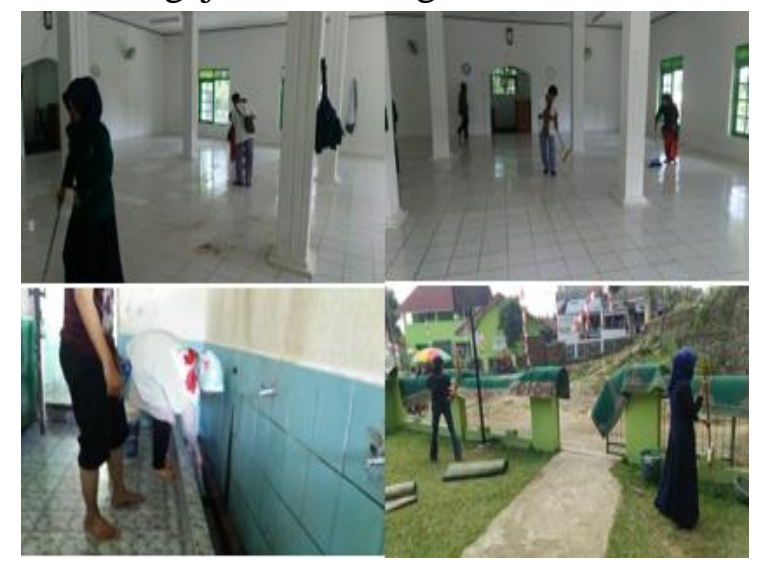

\section{Jum'at Bersih}

Yaitu kegiatan membersihkan masjid dan sekitar masjid bersama dengan remaja masjid dan warga.

Tujuan: Menjaga kebersihan dan keindahan masjid dan lingkungan serta mempererat hubungan silaturahi dengan para warga.

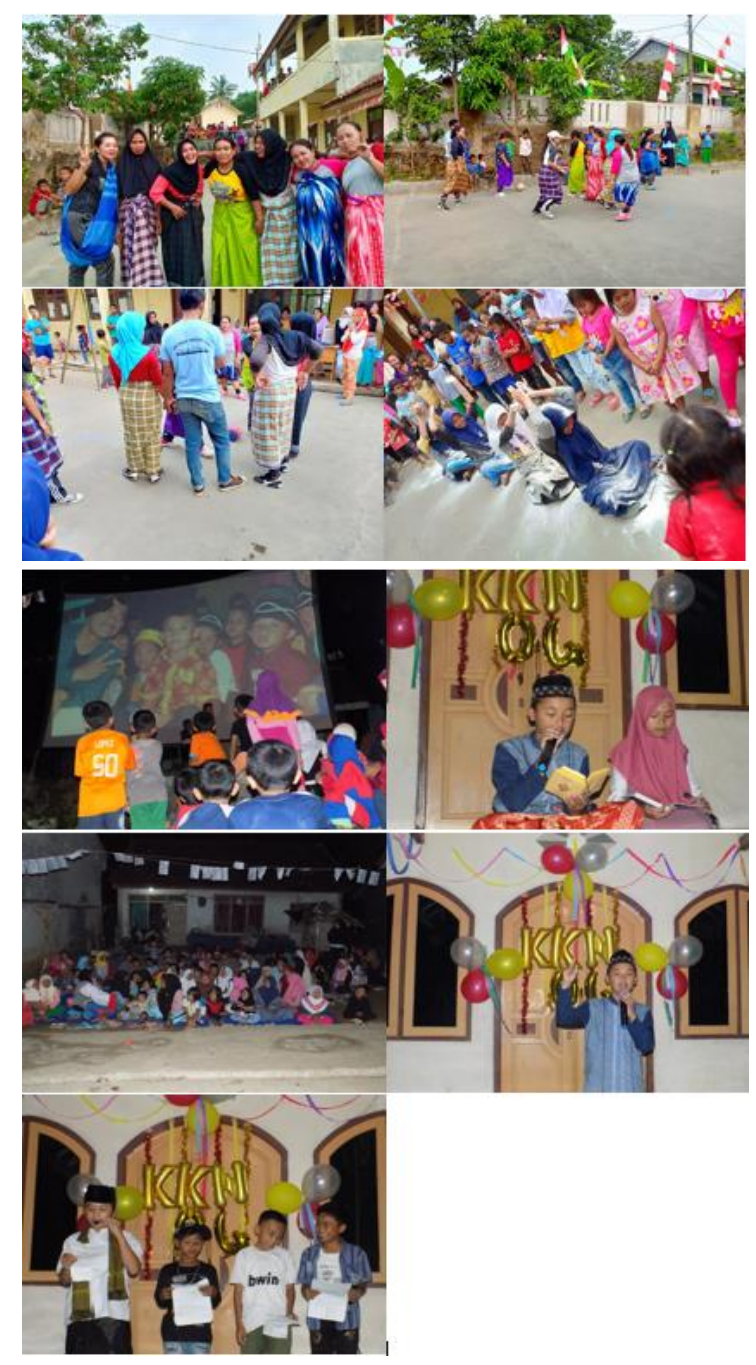

\section{Perlombaan 17 Agustus-an}

Tujuan :

- Mempererat tali silaturahim, kebersamaan, kekeluargaan, dan kerukunan antar sesama warga kampung Puswa.

- Meningkatkan rasa nasionalisme antar generasi untuk memperkuat ketahanan nasional.

- Meningkatkan semangat juang dalam meraih prestasi antar generasi.

- Memupuk jiwa sportifitas dalam berlomba. 


\section{KESIMPULAN}

Kegiatan KKN dengan sasaran masyarakat kampung Puswa sebagai bagian dari masyarakat secara umum berjalan dengan lancar sesuai dengan apa yang

\section{SARAN}

Berdasarkan hasil pelaksanaan program KKN yang dilaksanakan sejak 07 Agustus 2018 sampai dengan 07 September 2018 terdapat beberapa saran antara lain :

a. Program-program yang telah dilaksanakan oleh mahasiswa sebaiknya ada pengembangan atau tindak lanjut untuk peningkatan selanjutnya.

b. Hubungan yang sudah terjalin antara pihak universitas dengan pihak

\section{REFERENSI}

Iqtidha' Shirotil Mustaqim

Iqtidha' Shirotil Mustaqim

Taisiir Karimir Rahman

Efendi, M. (2009). Using Collaborative Technique to improve the ability of students at MTSN PULOSARI TULUNGAGUNG IN Writing Descriptive Text. Malang: University press.

Harun Rasyid, M. S. (2009). Pengertian 126 Bahasa. Jember: University of Jember.

Sadirman. (2012). Interkasi dan Motivasi Belajar Mengajar. jakarta: PT. Raja Grafindo persada, cet ke 21, hlm 25. direncanakan dalam matrik program kerja KKN berkat dukungan dan kerjasama antar warga dan pihak masyarakat.

masyarakat hendaknya dapat lebih ditingkatkan dan dapat memberikan umpan balik satu sama lainnya.

c. Agar melakukan perencanaan yang baik dalam merumuskan program, selalu melakukan koordinasi dengan pihak terkait sehingga kendala dan hambatan dapat tertangani.

http://kumpulanreferansi.blogspot.com/201 7/09/tujuan-dan-manfaatpembelajaran-bahasa

https://www.google.co.id/url?sa=t\&source =web\&rct=j\&url=http://ojs.unm.ac.i $\mathrm{d} /$ pubpend/article/download/1586/64 $\underline{8 \& v e d=2 \text { ahUKEwifXHo6rdAhUCU }}$ 30KHUfLDMgQFjAAegQIAhAB\& usg=AOvVaw30qi75zxYBOgNGhbc eo3wq

https://salamadin.com/perkembanganpengertian-teknologi/

https://www.coursehero.com/pengertianbahasa/ 